\title{
Development of a Guide to Preparation of Mathematics Questions Based on Higher Order Thinking Skills and Strengthening Character Education for Middle School Teachers
}

\author{
Ibrahim, Iwan Kuswidi, Nurul Arfinanti \\ Mathematics Education Study Program; Faculty of Science and Technology, UIN Sunan Kalijaga, Jl. \\ Marsda Adisucipto No. 1 Yogyakarta, Indonesia.
}

Korespondensi; Ibrahim, Email: ibrahim311079@gmail.com

\begin{abstract}
The objectives of public devotion based on nationally excelled research this covers: (1) to develop a mathematical problem composing guide based on HOTS and SCE for qualified Madrasah Tsanawiyah teachers, (2) to provide training a mathematical problem composing based on HOTS and SCE for qualified Madrasah Tsanawiyah teachers using the developed guide. This study uses a 4-D (Four D) development research design model according to Thiagarajan, et al (1974: 5). This research model includes 4 main stages, namely the defining stage, followed by the design stage, then towards the development stage, and finally the distribution phase. The research instruments included: (a) the scale of the assessment of the quality of mathematical composing guide based on HOTS and SCE for Madrasah Tsanawiyah teachers, (b) scale of appraisal user response for guidebook, and (c) the Pre Test and Post Test Problem Sheets. The results of the study concluded that the guidebook for mathematical problem composing for SMP / MTs based on HOTS and SCE met the specified quality criteria, which were at least in the good category. In this study, the developed guidebook obtained an evaluation in the excellent category. However, testing to determine the level of practicality has not been done.
\end{abstract}

Keywords: Guide; HOTS; Madrasah Tsanawiyah; Mathematical Problem; SCE

\section{Introduction}

The issue in the world of education in Indonesia today is about Higher Order Thinking Skills (HOTS). The issue becomes viral when national exam questions begin to refer to HOTS, such as the 2018 SMP/MTs mathematics national math exam. HOTS is a high-level thinking ability that requires students to discover, analyze, create, reflect, and argue (Kemdikbud, 2016). Higher Order Thinking Skills (HOTS) is the ability to think that is not merely to remember (recall), restate (restate), or refer without doing processing (recite). What is meant by thinking here is finding, analyzing, creating, reflecting, and arguing. While knowing, remembering, and repeating are not included in the category of thinking. Problems are complicated because there are unknown words whose meanings are not the same as higher-order thinking that involves reasoning processes (such as searching for meaning from context/stimulus).

The implementation of HOTS type questions can make the average value of students have decreased. Minister of Education and Culture (Mendikbud) Muhadjir Effendy said the average value of the 2018 SMP / MTs UN results has decreased. One aspect that caused the decline was the existence of HOTS questions on several items. The decrease in the average national examination scores for Indonesian language 0.32, English 0.61, Mathematics 6.99, and Natural Sciences 4.75 (Poskotanews, 2018).

According to Sadri Adam (2018), several things must be done so that the teacher can assist students in solving HOTS questions. First, the teacher must make habituation in the HOTS learning process. Second, the teacher must be able to make HOTS questions by applying them to various aspects of daily life and minimize the questions that emphasize the ability of students' memory. Third, optimizing 
HOTS questions through independent activities or forums such as In House Training (IHT) or Subject Teachers' Consultation (MGMP). Fourth, students must always hone the ability to analyze each item through teacher guidance by providing a sharp, focused and measurable understanding. Fifth, students are expected to be able to collaborate and transfer good knowledge between fellow students through the empowerment of peer tutors during the learning process in the classroom and outside the classroom.

Besides HOTS, the main focus in the world of education today is Strengthening Character Education (SCE). The SCE movement is the embodiment of the National Mental Revolution Movement launched by President Joko Widodo. The KDP movement needs to integrate, deepen, expand, and at the same time, harmonize various character education programs and activities. Of the four things, integration is often carried out in order to instil character education in schools. The integration in question can be in the form of guiding characters in classroom learning. Integration can also be done through the questions given.

There are five central values of the nation's character, namely: (a) religious, (b) nationalist, (c) independent, (d) cooperation, and (e) integrity. Religious values reflect faith in God Almighty, which is manifested in the behaviour of implementing religious teachings, respecting religious differences, upholding tolerance, living in harmony and peace with followers of other religions. Which includes sub-values of religious character values include: love of peace, tolerance, respect for differences, firmness, confidence, cooperation between religious adherents, friendship, protecting the small and excluded. Nationalist values are ways of thinking, behaving, and acting that show loyalty, care and high respect for the language, physical environment, social, cultural, economic, and political aspects of the nation, placing the interests of the nation and state above self and group interests. Which includes sub-values of the nationalist character values include: an appreciation of the nation's own culture, maintaining the nation's cultural wealth, willing to sacrifice, excel and excel, love the motherland, protect the environment, discipline, respect cultural diversity, ethnicity, and religion. Independent values are attitudes and behaviours that do not depend on others and use all energy, thoughts, time to realize hopes, dreams and ideals. Which includes sub-values of the independent character values include work ethic (hard work), positive, fighting spirit, professional, creative, courage, and become lifelong learners. The value of cooperation is a reflection of the act of appreciating the spirit of cooperation, establishing communication and friendship, helping. The sub-values of the character values of cooperation include respect, cooperation, inclusion, commitment to joint decisions, consensus agreement, help-help, solidarity, empathy, anti-discrimination, anti-violence, and voluntary attitudes. Integrity value is the value that underlies behaviour to make himself a person who can always be trusted in words, actions, and work has a commitment and loyalty to human values and morals (moral integrity). The sub-values of the integrity character values are honesty, loyalty, moral commitment, anti-corruption, justice, responsibility, example, and mutual respect (especially people with disabilities).

Based on the results of interviews conducted with several mathematics teachers at Madrasah Tsanawiyah (MTs), it is known that they still have difficulty in making HOTS questions and integrating the primary character education in mathematics learning. The absence of clear and specific guidelines on mathematics is one of the reasons why teachers are not optimal in making HOTS type questions. Also, madrassas in Indonesia are still underestimated, including the Madrasah Tsanawiyah. Parents prefer to send their children to regular public junior high school compared to the Madrasah Tsanawiyah. MTs mathematics teachers need training in making HOTS questions that contain character education so that the quality of students increases so that they can improve the quality of Madrasah.

Based on the above problems, researchers are interested in conducting community service based on superior national research. The objectives of this study are to develop guidelines for the preparation of HOTS and SCE-based mathematics questions for qualified Madrasah Tsanawiyah teachers. Furthermore, to provide training on the preparation of HOTS-based mathematics questions and SCE for qualified Madrasah Tsanawiyah teachers by using a guide that has been developed. Community service is carried out in the form of training on making mathematics questions based on HOTS and Strengthening Character Education (SCE) for MTs teachers in Indonesia. The research base used is development research, namely the development of guidelines for the preparation of HOTS and SCEbased mathematics questions for Madrasah Tsanawiyah teachers. 


\section{Research Methods}

Research and development methods or research and development are research methods used to produce specific products and test the effectiveness of these products (Sugiyono, 2012: 407). This study uses a 4-D (Four D) model development research design, according to Thiagarajan et al. (1974: 5). This research model includes four main stages, namely the defining stage, followed by the design stage, then towards the development stage, and finally, the distribution phase.

There are several types of data collected in this study, including the following: (a) data on the quality of the HOTS and SCE-based mathematical preparation manual for Madrasah Tsanawiyah teachers, and (b) data of user responses to the HOTS-based mathematics problem-solving manual and SCE for Madrasah Tsanawiyah teachers. The research instruments included: (a) the scale of the assessment of the quality of HOTS and SCE-based mathematics questions preparation for Madrasah Tsanawiyah teachers, (b) the scale of user response assessment in the guidebook, and (c) the Pre Test and Post Test Question Sheets.

The data obtained in this study were in the form of qualitative data, namely data on the quality of the preparation of HOTS and SCE-based mathematics questions for Madrasah Tsanawiyah teachers, and user responses to the HOTS and SCE-based mathematics questions preparation manual for Madrasah Tsanawiyah teachers. Qualitative data in the form of input are analyzed descriptively qualitatively. And then qualitative data on the checklist sheet is converted into numbers by steps, according to Widoyoko (2012: 110-112).

\section{Results and Discussion}

The result of this development research is the preparation of a guide book for the preparation of HOTS and SCE-based mathematics questions for qualified Madrasah Tsanawiyah teachers. This study also aims to determine the quality of instructional media applications based on expert judgment and student responses to the use of instructional media.

The data obtained from the process of making a manual book preparation of HOTS and SCE-based mathematics questions for qualified Madrasah Tsanawiyah teachers is as follows:

\section{Results in Define Stage}

Here are the results of the research at the define stage:

a. Results of Initial Analysis

The results of interviews with Madrasah Tsanawiyah mathematics teachers in the Yogyakarta region showed that many teachers still had difficulty in compiling HOTS and SCE-based questions. The difficulty is due to the lack of training that can improve the competence of mathematics teachers in compiling HOTS and SCE-based math problems. The absence of a clear guidebook is also a reason for teachers so that they have difficulty in developing questions based on HOTS and KDP. Based on these results, a guide book for the preparation of HOTS and SCE-based mathematics questions are needed for Madrasah Tsanawiyah teachers.

b. User Analysis Results

The results at this stage obtained data that mathematics teachers need guidebooks that can facilitate them in compiling HOTS and KDP-based questions. Madrasa mathematics teachers have the skills in compiling math problems; it's just that they sometimes still have difficulty in identifying questions that are included as hots or not. With this in mind, it is necessary to maximize training activities on HOTS and SCE-based mathematics problem-solving.

c. Curriculum Analysis Results

The results of curriculum analysis in the form of essential competencies that can be used as competencies in the matter of HOTS and SCE. Table 1 is the basic competency table that is reviewed in the HOTS and SCE-based questions preparation manual. 
Table 1. Results of Curriculum Analysis.

\begin{tabular}{|c|c|c|}
\hline No. & Basic Competencies & $\begin{array}{c}\text { Dimensions o } \\
\text { Cognitive } \\
\text { Process }\end{array}$ \\
\hline \multicolumn{3}{|c|}{ Class VII } \\
\hline 4.1 & $\begin{array}{l}\text { Solve problems related to the order of several integers and fractions (ordinary, } \\
\text { mixed, decimal, per cent) }\end{array}$ & $\mathrm{C} 4 \& \mathrm{C} 5$ \\
\hline 3.2 & $\begin{array}{l}\text { Explain and perform operations of integers and fractions using various operating } \\
\text { properties }\end{array}$ & $\mathrm{C} 4$ \\
\hline 4.2 & Solve problems related to integer and fraction counting operations & $\mathrm{C} 4 \& \mathrm{C} 5$ \\
\hline 4.3 & Solve problems related to numbers in the form of positive and negative integers & $\mathrm{C} 4 \& \mathrm{C} 5$ \\
\hline 3.4 & $\begin{array}{l}\text { Explains subsets, subsets, universal sets, empty sets, complement sets, and performs } \\
\text { binary operations on sets using contextual problems }\end{array}$ & \multirow{2}{*}{$\mathrm{C} 4 \& \mathrm{C} 5$} \\
\hline 4.4 & $\begin{array}{l}\text { Solve contextual problems related to sets, subsets, universal sets, empty sets, set } \\
\text { complements and binary operations on sets }\end{array}$ & \\
\hline 3.5 & $\begin{array}{l}\text { Explain algebraic forms and carry out operations on algebraic forms (addition, } \\
\text { subtraction, multiplication, and division) }\end{array}$ & \multirow{2}{*}{$\mathrm{C} 4$} \\
\hline 4.5 & Solve problems related to algebraic forms and operations on algebraic forms & \\
\hline 3.6 & Explain the linear equation and inequality of one variable and solve it & \multirow{2}{*}{$\mathrm{C} 4$} \\
\hline 4.6 & Solve problems related to linear and one variable inequalities & \\
\hline 3.7 & Explain the ratio of two quantities (the units are the same and different) & \multirow[b]{2}{*}{$\mathrm{C} 4$} \\
\hline 4.7 & $\begin{array}{l}\text { Solve problems related to the ratio of two quantities (the units are the same and } \\
\text { different) }\end{array}$ & \\
\hline 3.8 & $\begin{array}{l}\text { Distinguish comparative worth and turn around values using data tables, graphs, } \\
\text { and equations }\end{array}$ & \multirow[t]{2}{*}{$\mathrm{C} 4-\mathrm{C} 5$} \\
\hline 4.8 & Resolve issues related to comparison of worth and turn around values & \\
\hline 3.9 & $\begin{array}{l}\text { Know and analyze various situations related to social arithmetic (sales, purchases, } \\
\text { deductions, profits, losses, single interest, percentages, gross, net, tare) }\end{array}$ & \multirow{2}{*}{ C4 C5 } \\
\hline 4.9 & $\begin{array}{l}\text { Solve problems related to social arithmetic (sales, purchases, deductions, profits, } \\
\text { losses, single interest, percentages, gross, net, tare) }\end{array}$ & \\
\hline 3.10 & $\begin{array}{l}\text { Analyzing the relationship between angles as a result of two parallel lines cut by } \\
\text { the transverse line }\end{array}$ & \multirow[b]{2}{*}{$\mathrm{C} 4$} \\
\hline 4.10 & $\begin{array}{l}\text { Resolving problems related to the relationship between angles as a result of two } \\
\text { parallel lines cut by the transverse line }\end{array}$ & \\
\hline 3.11 & $\begin{array}{l}\text { Relates circumferential and broad formulas for various types of rectangles (squares, } \\
\text { rectangles, split diamonds, long chains, trapezius and kites) and triangles }\end{array}$ & \multirow{2}{*}{$\mathrm{C} 4$} \\
\hline 4.11 & $\begin{array}{l}\text { Solve contextual problems related to the area and circumference of rectangles } \\
\text { (squares, rectangles, rhombus, rows, trapezoid and kite) and triangles }\end{array}$ & \\
\hline 3.12 & $\begin{array}{l}\text { Analyzing the relationship between data by presenting it (tables, line diagrams, bar } \\
\text { charts, and pie charts) }\end{array}$ & \multirow{2}{*}{$\mathrm{C} 4$} \\
\hline 4.12 & $\begin{array}{l}\text { Present and interpret data in the form of tables, line charts, bar charts, and pie } \\
\text { charts }\end{array}$ & \\
\hline \multicolumn{3}{|c|}{ 至 } \\
\hline 3.1 & $\begin{array}{l}\text { Make generalizations of patterns in sequence numbers and configuration } \\
\text { configurations }\end{array}$ & $\mathrm{C} 4$ \\
\hline 4.1 & Resolve problems related to patterns in sequence numbers and configuration objects & $\mathrm{C} 4$ \\
\hline 3.2 & $\begin{array}{l}\text { Explain the position of points in the Cartesian coordinate plane that is associated } \\
\text { with contextual problems }\end{array}$ & \multirow[t]{2}{*}{$\mathrm{C} 4$} \\
\hline 4.2 & Resolve problems related to the position of points in the Cartesian coordinate plane & \\
\hline 3.3 & $\begin{array}{l}\text { Describe and state relationships and functions using various representations (words, } \\
\text { tables, graphs, diagrams, and equations) }\end{array}$ & \multirow[t]{2}{*}{$\mathrm{C} 4-\mathrm{C} 5$} \\
\hline 4.3 & Solve problems related to relations and functions by using various representations & \\
\hline 3.4 & $\begin{array}{l}\text { Analyzing linear functions (as straight-line equations) and interpreting the graphs } \\
\text { that are associated with contextual problems }\end{array}$ & \multirow[t]{2}{*}{$\mathrm{C} 4 \mathrm{C} 5$} \\
\hline 4.4 & Solve contextual problems related to linear functions as straight-line equations & \\
\hline
\end{tabular}


No.

Basic Competencies

Dimensions of

Cognitive

Process

3.5 Explain the system of two-variable linear equations and their solutions related to contextual problems

4.5 Solve problems related to the two-variable linear equation system

3.6 Explain and prove the Pythagorean theorem and Pythagorean triple

4.6 Solve problems related to the Pythagorean theorem and Pythagorean triple

3.7 Explain the central angle, circumferential angle, arc length, and area of a circle, and their relationship

4.7 Solve problems relating to the central angle, the circumferential angle, the length

4.7 of the arc, and the area of the circle's circle, and the relationship

3.8 Explain the tangent lines of external fellowship and fellowship in two circles and how to paint it

4.8 Resolving issues relating to the tangent of the external alliance and the alliance in

4.8 the two circles

3.9 Differentiate and determine the surface area and volume of flat side spaces (cubes,

3.9 beams, prisms and pyramid)

4.9 Solve problems related to surface area and volume of flat side spaces (cubes,

4.9 beams, prime and pyramid), and their combinations

3.10 Analyze data based on data distribution, average value, median, mode, and distribution of data to conclude, make decisions, and make predictions

4.10 Fix and solve problems related to data distribution, average values, median, mode,

4.10 and distribution of data to conclude, make decisions, and make predictions

3.11 Explain the empirical and theoretical opportunities of an event from an experiment

4.11 Solve problems related to practical and theoretical opportunities of an event from an experiment

\section{Class IX}

3.1 Explain and carry out operations of numbers of rational numbers and roots, and their properties

4.1 Solve problems related to the operation properties of round rank numbers and root

4.1 shapes

3.2 Explain quadratic equations and their characteristics based on their roots and how to solve them

4.2 Solve problems related to quadratic equations

3.3 Explain quadratic functions using tables, equations, and graphs

4.3 Present quadratic functions using tables, equations, and graphs

3.4 Explain the relationship between coefficients and discriminant squared functions with the graph

4.4 Present and solve contextual problems using the properties of quadratic functions

3.5 Explain geometrical transformations (reflection, translation, rotation, and dilation) associated with contextual problems

4.5 Solve contextual problems related to geometry transformation (reflection, translation, rotation, and dilation)

3.6 Explain and determine congruence and harmony between flat shapes

4.6 Resolving problems related to congruence and harmony between the flat structures

3.7 Generalize surface area and volume of various curved side spaces (tubes, cones, and spheres)

Solve contextual problems related to surface area and volume of arcing (cylindrical,

4.7 conical, and spherical side space), as well as the combination of several curved sided space

\section{Results in the Design Stage}

Here are the results of the design phase conducted by researchers:

Template Guidebook

Chapter I Introduction 

A. Background
B. Purpose
C. Expected Results

Chapter II Basic Concepts on HOTS-Based Questions and Strengthening Character Education
A. Definition of HOTS
B. Characteristics of HOTS Questions
C. HOTS Cognitive Levels
D. About HOTS and Difficulty Levels
E. Strengthening Character Education

F. Steps in Formulating HOTS-Based Questions and Strengthening Character Education

Chapter III Formulation of HOTS-Based Questions and Strengthening Character Education
A. Mathematical Characteristics
B. Analysis of Basic Competencies
C. Examples of HOTS-Based Problem Stimulus and Strengthening Character Education
D. Explanation of Basic Competencies Become Indicators
E. Arranging the Grid
F. HOTS-Based Question Cards and Strengthening Character Education

\section{Results in the Develop Stage}

The results at each stage of development are explained as follows:

a. Creation of Initial Products

The steps for making a HOTS and SCE-based math problem handbook for Junior High School teachers will be presented as follows:

1) Make a Book Cover

2) Make a Table of Contents

3) Write the contents of the Guidebook

b. Results in the Validation (Expert Assessment) and Teacher Stage

Here are the results of validation from experts

Table 2. Results of Validator Ratings.

\begin{tabular}{ccccc}
\hline VALIDATOR ASSESSMENT & \multicolumn{4}{c}{ Validator } \\
\cline { 2 - 5 } & $\mathbf{1}$ & $\mathbf{2}$ & $\mathbf{3}$ & $\mathbf{4}$ \\
\hline Average Score & 3,37 & 3,53 & 3,53 & 3,58 \\
\hline
\end{tabular}

Based on the data above we get information that the lowest average is 3.37 or in the "very good" category. In other words, the quality of the guidebook that has been developed has reached the specified target.

\section{Persentase Keidealan}

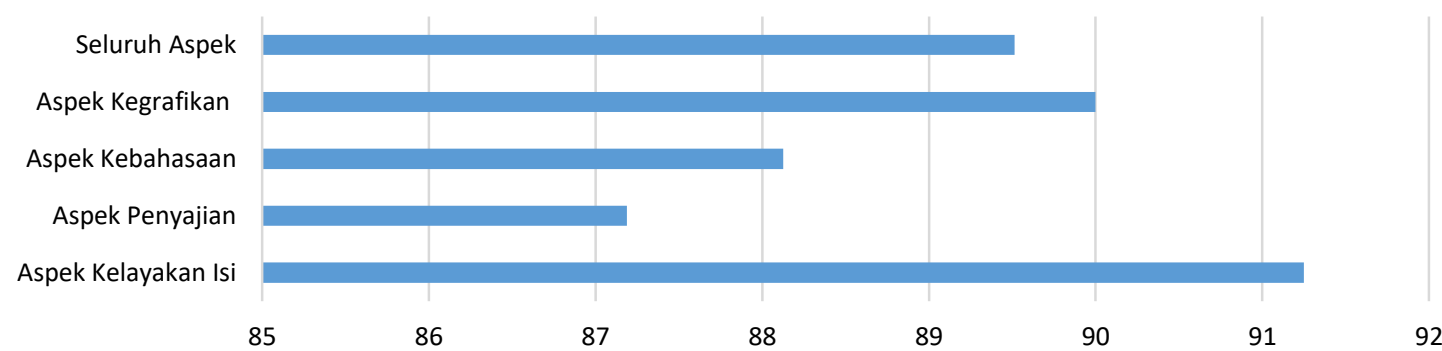

Figure 1. Teacher Assessment Results.

The teacher's response to the HOTS and SCE-based math questions handbook overall was in the very good category. This was also shown by the enthusiasm of the teacher in reading and studying the manual during the workshop. The teacher uses the textbook to make math problems for junior high school based on HOTS and SCE. The teacher also provides input so that the sample questions contained in the manual are reproduced. 


\section{Dissemination}

Dissemination or distribution of products is done by publishing books that have been tested and revised based on the results of field trials. A reputable publisher publishes the book. Here is the front view of the manual after it has been released.

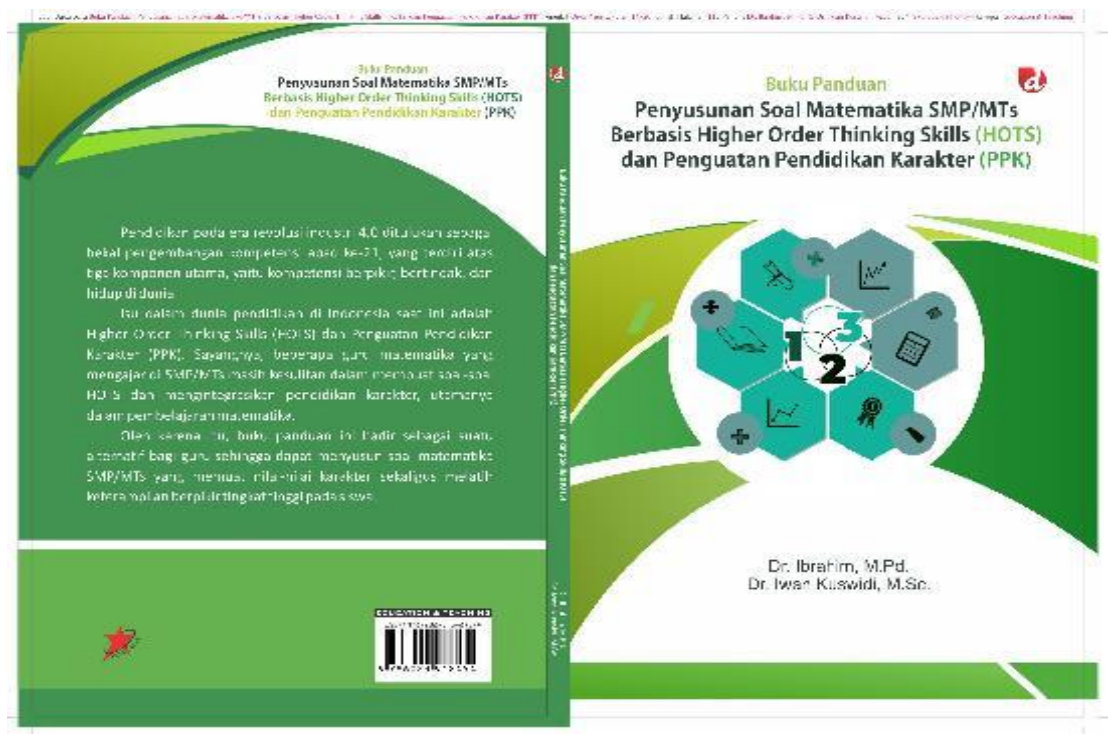

Figure 2. Final Display of the Book.

\section{Discussion}

Higher-Order Thinking Skill (HOTS) is a type of thinking by exploring issues concerning a knowledge related to matters that are not clearly defined and do not have definite answers. While the problems based on Strengthening Character Education (SCE) are needed as a form of teacher preventive efforts for students in the future. The guidebook was developed to make it easier for Madrasah Tsanawiyah teachers to compile math problems based on HOTS and SCE. Guidelines for the preparation of HOTS and SCE-based math questions can be practised directly by the teacher through workshop activities. The workshop included training on making math questions based on Higher Order Thinking Skills (HOTS) and Strengthening Character Education (SCE) for Madrasah Tsanawiyah teachers. The ability of teachers to make math problems based on HOTS and SCE becomes exciting findings during the implementation of the workshop activities. The teacher is asked to prepare questions together with HOTS and SCE-based question indicators in groups. The teacher representatives in each group then presented the results in front of the other workshop participants so that there were discussions with other teachers and workshop presenters. The following are examples of questions that have been made by the teacher.

Basic Competence : Linking the circumference formula and area for various types of rectangles (square, rectangular, rhombus, jajargenjang, trapezoid and kite laying) and triangles.

SCE : Nationalist, Care for the Environment

Problem Indicator : Presented about a story about a rectangular garden. If the circumference (less than $50 \mathrm{~m}$ ) and the required elements are known, students can determine the number of trees planted in the garden.

Problem

: In order to commemorate Earth Day, the Government calls on every citizen who owns a yard to plant trees for greening. Mr. Ahmad has a rectangular garden which will be planted with sengon trees. The length of the garden is 4 meters more than its width, the circumference is 40 meters. If the spacing between trees is 4 meters, then many trees planted are ...
a. 8 trees
b. 12 trees
c. 16 trees
d. 20 trees 


\section{Conclusion}

Based on the results of the above research, it can be concluded that the guide book for Mathematics / Mathematical Mathematics / Junior High School Mathematics Mathematics based on HOTS and SCE has met the specified quality criteria, which is at least in the good category. In this study, the developed guidebook obtained an evaluation in the good category. However, testing to determine the level of practicality has not been done.

\section{Acknowledgement}

The author would like to thank the Directorate of Islamic Religious Higher Education Ministry of Religion of the Republic of Indonesia for funding this research activity through the 2019 National Flagship Research Dedication Gran

\section{Referensi}

[1] Adam, Sadri. 2018. Soal HOTS antara Kemampuan Siswa dan Kompetensi Guru? Diakses pada August 24, 2018, dari https://www.kompasiana.com/sadriadam/5add708a5e13734e037429a2/soal-hots-antara-kemampuan-siswa-dankompetensi-guru.

[2] http://poskotanews.com/2018/05/28/hasil-un-smpmts-tahun-2018-secara-keseluruhan-turun-317-poin/ Diakses pada August 24, 2018

[3] http://kabar24.bisnis.com/read/20180525/255/799718/mengapa-hasil-un-smp-2018-turun-begini-penjelasan-mendikbudmuhadjir/ Diakses pada August 24, 2018

[4] Peraturan Menteri Pendidikan dan Kebudayaan Nomor 20 Tahun 2016 Tentang Standar Kompetensi Lulusan Pendidikan Dasar dan Menengah.

[5] Peraturan Menteri Pendidikan dan Kebudayaan Nomor 21 Tahun 2016 Tentang Standar Isi Pendidikan Dasar dan Menengah

[6] Peraturan Menteri Pendidikan dan Kebudayaan Nomor 22 Tahun 2016 Tentang Standar Proses Pendidikan Dasar dan Menengah.

[7] Peraturan Menteri Pendidikan dan Kebudayaan Nomor 23 Tahun 2016 Tentang Standar Penilaian Pendidikan.

[8] Thiagarajan, S., Semmel, D.S., \& Semmel, M.I. $1974 . \quad$ Instructional development for training teacher of exceptional children. Bloomington Indiana: Indiana University

[9] Tim Penyusun. Konsep dan Pedoman Penguatan Pendidikan Karakter Tingkat Sekolah Dasar dan Sekolah Mengengah Pertama. Kementerian Pendidikan dan Kebudayaan Republik Indonesia.

[10] Tim Penyusun. 2016. Panduan Penyusunan Soal Higher Order Thinking Skills (HOTS). Kementerian Pendidikan Nasional.

[11] Sugiyono. 2012. Metode Penelitian Kuantitaf Kualitatif dan R\&D. Bandung, Alfabeta.

[12] Widana, I Wayan, dkk. 2017. Modul Penyusunan Soal Higher Order Thinking Skills (HOTS). Jakarta, Direktorat Pembinaan SMA, Dirjen Dikdasmen, Kementerian Pendidikan dan Kebudayaan.

[13] Widoyoko, Putro. 2012. Evaluasi Program Pembelajaran. Yogyakarta, Pustaka Pelajar. 